\title{
Functional analysis of naturally occurring DCLRE1C mutations and correlation with the clinical phenotype of ARTEMIS deficiency
}

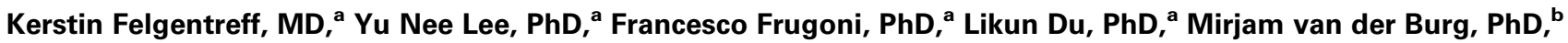 \\ Silvia Giliani, PhD, ${ }^{c}$ Ilhan Tezcan, MD, ${ }^{d}$ Ismail Reisli, MD, ${ }^{e}$ Ester Mejstrikova, MD, ${ }^{f}$ Jean-Pierre de Villartay, PhD, ${ }^{9}$ \\ Barry P. Sleckman, MD, PhD, ${ }^{h}$ John Manis, MD, PhD, and Luigi D. Notarangelo, MD ${ }^{\mathbf{a}, \mathbf{j}} \quad$ Boston, Mass, Rotterdam, \\ The Netherlands, Brescia, Italy, Ankara and Konya, Turkey, Prague, Czech Republic, Paris, France, and St Louis, Mo
}

Background: The endonuclease ARTEMIS, which is encoded by the DCLRE1C gene, is a component of the nonhomologous endjoining pathway and participates in hairpin opening during the $\mathrm{V}$ (D)J recombination process and repair of a subset of DNA double-strand breaks. Patients with ARTEMIS deficiency usually present with severe combined immunodeficiency (SCID) and cellular radiosensitivity, but hypomorphic mutations can cause milder phenotypes (leaky SCID).

Objective: We sought to correlate the functional effect of human DCLRE1C mutations on phenotypic presentation in patients with ARTEMIS deficiency.

Methods: We studied the recombination and DNA repair activity of 41 human DCLRE1C mutations in Dclre1c ${ }^{-/-} \mathrm{v}$-abl kinase-

\footnotetext{
From ${ }^{a}$ the Division of Immunology and ${ }^{\mathrm{i}}$ the Department of Transfusion Medicine, Boston Children's Hospital, Harvard Medical School, Boston; ' nology, Erasmus Medical Center, Rotterdam; ${ }^{\mathrm{c} A n g e l o}$ Nocivelli Institute for Molecular Medicine, Department of Pediatrics, University of Brescia; ${ }^{\mathrm{d}}$ Immunology Department, Ihsan Dogramaci Children's Hospital, Hacettepe University Medical School, Sihhiye, Ankara; ${ }^{e}$ the Department of Pediatric Immunology and Allergy, Necmettin Erbakan University, Meram Medical Faculty, Konya; ${ }^{\mathrm{f} C L I P-C h i l d h o o d ~ L e u k e-~}$ mia Investigation Prague, Department of Pediatric Hematology and Oncology, 2nd Faculty of Medicine and University Hospital Motol, Charles University, Prague;

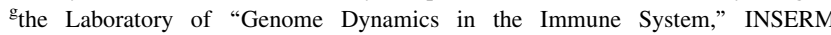
UMR1163, Université Paris Descartes Sorbonne Paris Cité, Institut Imagine, Paris; hthe Department of Pathology and Immunology, Washington University School of Medicine, St Louis; and ${ }^{j}$ the Harvard Stem Cell Institute, Harvard University, Boston. Supported in part by grants P01 AI076210-05 and R01AI00887 from the National Institute of Allergy and Infectious Diseases/National Institutes of Health (to L.D.N.) and March of Dimes grant 1-FY13-500 (to L.D.N.). K.F. received funding from the German Research Foundation (FE 1253/1-1). The JpdeV laboratory is partly funded by Ligue Nationale contre le Cancer (Equipe Labellisée La LIGUE). E.M. is supported by MZCR 00064203 and CZ.2.16/3.1.00/21540.

Disclosure of potential conflict of interest: $\mathrm{K}$. Felgentreff has received funding from the German Research Foundation (DFG). M. van der Burg's institution has received an Innovational Research Incentives Scheme Vidi (ZonMw) grant (no. 91712323). L. D. Notarangelo is employed by Boston Children's Hospital; has received compensation for board membership from the NIAID and Meyer Children's Hospital, as well as for his role as an Associate Editor at the Journal of Allergy of Clinical Immunology, Journal of Clinical Immunology, and Clinical Immunology; has received grants from the March of Dimes (grant no. 1-FY13-500); and receives royalties from UpToDate. The rest of the authors declare that they have no relevant conflicts of interest.

Received for publication January 21, 2015; revised March 4, 2015; accepted for publication March 13, 2015.

Available online April 25, 2015.

Corresponding author: Luigi D. Notarangelo, MD, Division of Immunology, Children's Hospital Boston, Manton Centre for Orphan Disease Research, Harvard Stem Cell Institute, Harvard University, Karp Research Building, Rm 12017, 1 Blackfan Circle, Boston, MA 02115. E-mail: Luigi.Notarangelo@childrens.harvard.edu.

$0091-6749 / \$ 36.00$

(C) 2015 American Academy of Allergy, Asthma \& Immunology

http://dx.doi.org/10.1016/j.jaci.2015.03.005
}

transformed pro-B cells retrovirally engineered with a construct that allows quantification of recombination activity by means of flow cytometry. For assessment of DNA repair efficacy, resolution of $\gamma \mathrm{H} 2 \mathrm{AX}$ accumulation was studied after ionizing radiation. Results: Low or absent activity was detected for mutations causing a typical SCID phenotype. Most of the patients with leaky SCID were compound heterozygous for 1 loss-of-function and 1 hypomorphic allele, with significant residual levels of recombination and DNA repair activity. Deletions disrupting the C-terminus result in truncated but partially functional proteins and are often associated with leaky SCID. Overexpression of hypomorphic mutants might improve the functional defect. Conclusions: Correlation between the nature and location of DCLRE1C mutations, functional activity, and the clinical phenotype has been observed. Hypomorphic variants that have been reported in the general population can be disease causing if combined in trans with a loss-of-function allele. Therapeutic strategies aimed at inducing overexpression of hypomorphic alleles might be beneficial. (J Allergy Clin Immunol 2015;136:140-50.)

Key words: $V(D) J$ recombination, nonhomologous end-joining, DNA repair, ARTEMIS deficiency, DCLRE1C mutations, severe combined immunodeficiency

The endonuclease ARTEMIS, which is encoded by the gene DCLRE1C (NG_007276.1; ENSG00000152457), is an essential component of the $\mathrm{V}(\mathrm{D}) \mathrm{J}$ recombination machinery during $\mathrm{T}$ and B-cell development and plays an important role in the nonhomologous end joining (NHEJ)-mediated DNA doublestrand break repair pathway. ${ }^{1}$

The $\mathrm{V}(\mathrm{D}) \mathrm{J}$ recombination process is initiated by the recombination-activating gene (RAG) products $^{2}$ RAG1 and RAG2, which bind to recombination signal sequences (RSSs) adjacent to the coding $\mathrm{V}-$, D-, and J-segments and induce a DNA double-strand break, leaving hairpin structure at coding ends. On phosphorylation by the DNA protein kinase catalytic subunit complex, ARTEMIS is recruited and mediates hairpin opening through its endonuclease activity. ${ }^{3}$ The open ends at the overhangs can be modified by ARTEMIS' endonuclease and exonuclease activities before the X-ray repair cross-complementing protein 4/XRCC4like factor/DNA Ligase 4 (XCRR4/XLF/LIG4) complex seals the DNA strands. Defects in ARTEMIS result in aberrant hairpin opening and give rise to increased numbers of P-nucleotides in the coding joints. ${ }^{4}$ In contrast to what is observed in defects of other members of the NHEJ pathways, the blunt ends formed at the RSS 

Abbreviations used
A-MuLV: Abelson murine leukemia virus
ExAC: Exome Aggregation Consortium
GFP: Green fluorescent protein
IR: Ionizing radiation
LOF: Loss of function
MFI: Mean fluorescent intensity
NHEJ: Nonhomologous end-joining
OS: Omenn syndrome
RAG: Recombination-activating gene
RSS: Recombination signal sequence
SCID: Severe combined immunodeficiency
WT: Wild-type

cleavage sites (yielding excision circles or inversions) rejoin normally in the absence of ARTEMIS.

The ARTEMIS protein is a member of the metallo- $\beta$-lactamase superfamily and is organized into an $\mathrm{N}$-terminal region containing the $\beta$-lactamase homology domain, a central $\beta$-CASP domain, and a C-terminal region. The first 2 domains have critical catalytic function, whereas the $\mathrm{C}$-terminus plays a role in protein stabilization and regulation of function. ${ }^{5,6}$

ARTEMIS is also involved in an ataxia-telangiectasia mutated protein (ATM)-dependent slow-kinetic NHEJ DNA repair pathway, where it is required to modify nonligatable ends of DNA breaks before they can be rejoined. ${ }^{7,8}$ This type of break occurs in a small fraction (around 10\%) of DNA double-strand breaks after exposure to ionizing irradiation and requires more time for repair, resulting in delayed repair kinetics.

By affecting V(D)J recombination, mutations of the DCLRE1C gene impair T- and B-cell development, leading to $\mathrm{T}^{-} \mathrm{B}^{-}$severe combined immunodeficiency (SCID), which is associated with a mild form of cellular radiosensitivity. ${ }^{9}$

The most common causes for DCLRE1C loss-of-function alleles are large deletions affecting the first 4 exons and a nonsense founder mutation, which has been described in Athabascanspeaking Native Americans. ${ }^{10}$ However, missense mutations affecting highly conserved residues can also abrogate protein function. ${ }^{11,12}$ On the other hand, hypomorphic mutations in DCLRE1C retaining residual function have been reported in patients with $\mathrm{B}^{-/ \text {low }} \mathrm{T}^{\text {low }}$ "leaky" SCID or Omenn syndrome (OS).

We have recently reported correlation between recombination activity of naturally occurring RAG1 mutant proteins and the clinical and immunologic phenotype associated with RAGl mutations. ${ }^{14}$ In that study RAG1 recombination activity was studied in murine $\operatorname{Ragl}^{-/-} \mathrm{V}$-abl kinase-transformed pro-B-cell lines retrovirally engineered with a recombination construct and transduced with RAG1-expressing vectors, thus allowing green fluorescent protein (GFP) expression as a readout of recombination proficiency. Using a similar approach, we attempted to measure $\mathrm{V}(\mathrm{D}) \mathrm{J}$ recombination and DNA repair activity levels of 41 naturally occurring mutated DCLRE1C products caused by point mutations or small deletions.

\section{METHODS}

\section{Patient selection based on genotype}

Clinical and molecular data from patients with ARTEMIS deficiency caused by missense mutations or small deletions in DCLRE1C were collected from previous reports or were provided by physicians from Europe and the United
States, according to protocols approved by local institutional review boards. Based on the clinical and immunologic presentation, each patient was assigned to subgroups of $\mathrm{T}^{-} \mathrm{B}^{-}$SCID or a leaky/atypical presentation referred to as "leaky SCID," the latter including patients with OS, according to criteria defined by the Primary Immune Deficiency Treatment Consortium. ${ }^{15}$

\section{Determination of relative recombination activity levels associated with mutations in DCLRE1C}

Analysis of recombination activity was performed in a cellular system of murine Dclrelc ${ }^{-1-}$ Abelson murine leukemia virus (A-MuLV)-transformed pro-B cells (see Fig E1, A, in this article's Online Repository at www. jacionline.org), ${ }^{16}$ as previously described. ${ }^{14,17}$ Cells were retrovirally transduced to insert an inverted GFP cassette flanked by 2 RSSs and subjected to limiting dilution to isolate pro-B cells containing only 1 copy of such a cassette (see Fig E1, B). Finally, in vitro mutagenized $\mathrm{h} D C L R E 1 C$ cDNAs were individually introduced into engineered Dclrelc ${ }^{-1-}$ A-MuLV pro-B cells by using retroviral vectors. Efficient mutagenesis was confirmed by means of Sanger sequencing in constructs and transduced cells.

Targeting of the RSSs contained in the recombination cassette allows GFP expression as a functional readout of recombination activity that can be quantified by means of flow cytometry on gating on cells expressing both hCD4 and hCD2. For assessment of recombination and DNA repair activities, Dclre1c $^{-1-}$ abl pro-B cells were blocked in G0/G1 cell-cycle phases for 72 hours by means of culture in $3 \mu \mathrm{mol} / \mathrm{L}$ of the $\mathrm{v}$-abl kinase inhibitor imatinib (STI-571; Novartis, Basel, Switzerland), which allows the Rag1/Rag2 complex to initiate the recombination process with higher efficiency (see Fig E2 in this article's Online Repository at www.jacionline.org). Experiments were carried out in wild-type (WT) mock-transduced cells and sets of up to 8 mutants at a time and were run in triplicates. Recombination activity levels were assessed as percentages of GFP expression detected in cells transduced with WT DCLRE1C after subtraction of background activity observed in mock-transduced cells.

\section{Determination of DNA repair activity levels}

NHEJ-mediated DNA repair was assessed in WT, mock-transduced, and mutant-transduced cells at 1, 8, 24, and 36 hours after ionizing radiation (IR) with $10 \mathrm{~Gy}$. Phosphorylated H2A histone family, member X ( $\gamma \mathrm{H} 2 \mathrm{AX})$ was quantified by means of flow cytometry (Phospho Histo H2A.X [Ser139, 20E3; Cell Signaling, Danvers, Mass], 5763S; rabbit [DA1E] IgG XP isotype control [Cell Signaling], 5742). Because chromosomal replication is known to cause formation of $\gamma \mathrm{H} 2 \mathrm{AX}$ foci, ${ }^{18}$ for this study, cell cycles were blocked in G0/G1 for 72 hours. DNA repair efficiencies were calculated based on mean fluorescent intensities (MFIs) at 36 hours after IR. For cells transduced with either WT or mutant constructs of DCLRE1C, the $\gamma \mathrm{H} 2 \mathrm{AX}$ MFI was subtracted from mock MFI, and activities were assessed as percentages of WT construct performance at 36 hours after exposure to 10 Gy of IR.

\section{Southern blotting}

To assess the number of DCLRE1C vector integrations in transduced cells, $15 \mu \mathrm{g}$ of genomic DNA extracted from Dclrelc $c^{-1-}$ abl pro-B cells was digested with EcoR1, HindIII, and NcoI (NEB, Ipswich, Mass), run on TBE gels, and blotted on a $0.45-\mu \mathrm{m}$ nylon membrane (Whatman Turbo Blotter Transfer System; Fisher Scientific, Waltham, Mass). Membranes were hybridized with digoxigenin-labeled probes detecting $\mathrm{h} C D 4$ and $\mathrm{h} C D 2$, respectively, and signal detection was performed with an anti-digoxigenin antibody-based system (Roche, Basel, Switzerland), according to the manufacturer's instructions.

\section{Quantitative real-time PCR}

Quantitative PCR was performed with the $\Delta \Delta C T$ method and normalized to WT gene expression. Additional information and primer sequences are listed in the Methods section in this article's Online Repository at www. jacionline.org. 
TABLE I. Genotype and clinical presentation of ARTEMIS-deficient patients

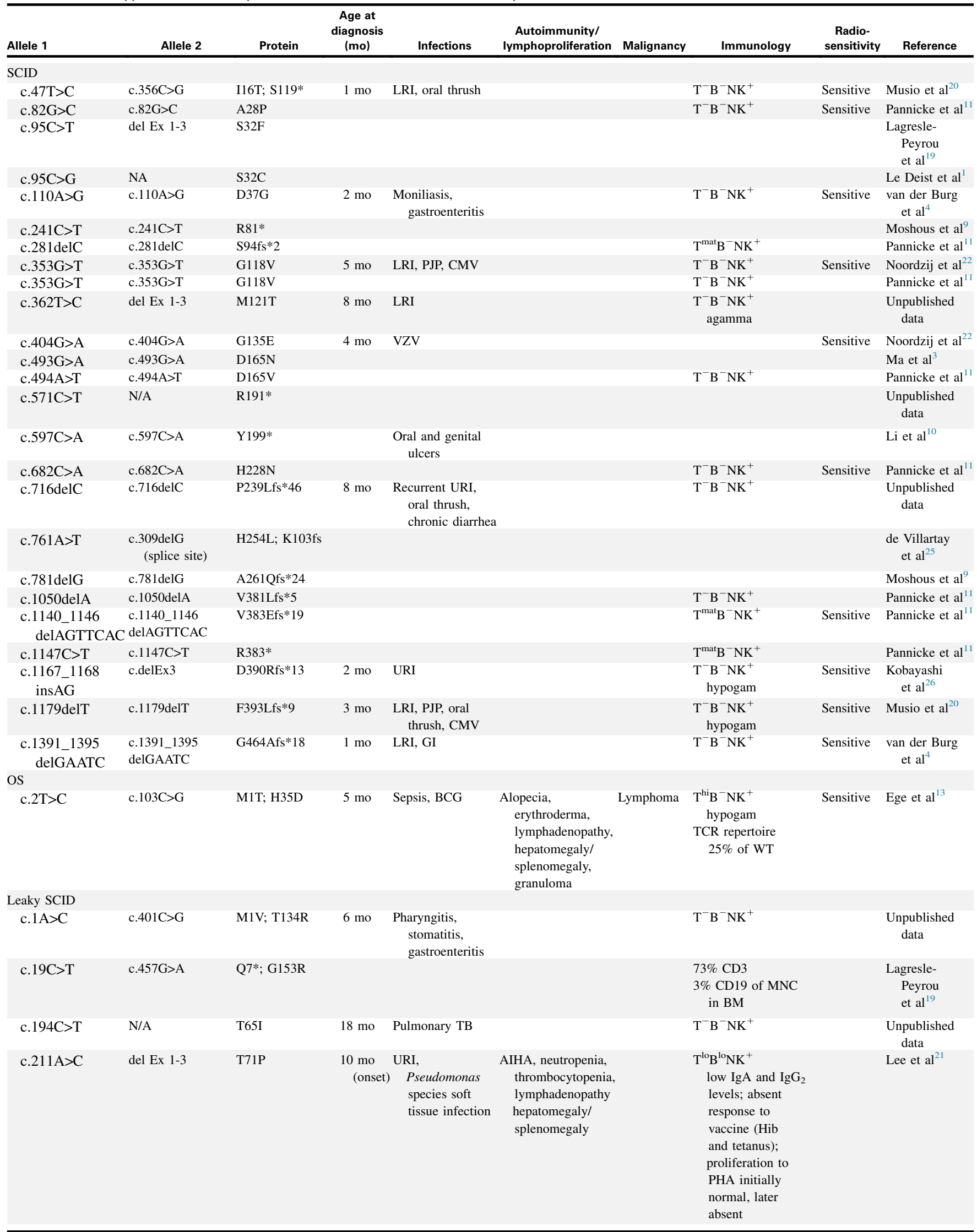




\begin{tabular}{|c|c|c|c|c|c|c|c|c|c|}
\hline Allele 1 & Allele 2 & Protein & $\begin{array}{c}\text { Age at } \\
\text { diagnosis } \\
\text { (mo) }\end{array}$ & Infections & $\begin{array}{c}\text { Autoimmunity/ } \\
\text { lymphoproliferation }\end{array}$ & Malignancy & Immunology & $\begin{array}{l}\text { Radio- } \\
\text { sensitivity }\end{array}$ & Reference \\
\hline c. $211 \mathrm{~A}>\mathrm{C}$ & del Ex 1-3 & $\mathrm{T} 71 \mathrm{P}$ & Birth & $\begin{array}{l}\text { URI, } \\
\text { oral candidiasis }\end{array}$ & AIHA & & $\begin{array}{l}\mathrm{T}^{\mathrm{lo}} \mathrm{B}^{-} \mathrm{NK}^{+} \\
\text {low IgG levels, } \\
\text { absent IgA; } \\
\text { decreased TREC } \\
\text { numbers; } \\
\text { proliferation to PHA } \\
\text { initially normal, } \\
\text { later absent }\end{array}$ & & Lee et $\mathrm{al}^{21}$ \\
\hline $\begin{array}{r}\text { c.207_209 } \\
\text { delGTT }\end{array}$ & c. $377 \mathrm{G}>\mathrm{A}$ & L70del; G126D & $4.5 \mathrm{y}$ & $\begin{array}{l}\text { URI, Candida } \\
\text { species }\end{array}$ & AIHA & & $\begin{array}{l}\mathrm{T}^{\mathrm{lo}} \mathrm{B}^{+} \mathrm{NK}^{+} \text {hypogam } \\
\text { no specific antibody } \\
\text { response }\end{array}$ & Sensitive & Evans et $\mathrm{al}^{23}$ \\
\hline c. $400 \mathrm{~A}>\mathrm{G}$ & $\begin{array}{l}\text { del Ex 1+ } \\
\quad(\text { not } \\
\text { specified) }\end{array}$ & $\mathrm{T} 134 \mathrm{~A}$ & & & Lymphadenopathy & & $\begin{array}{c}\mathrm{T}^{\mathrm{lo}} \text {, polyclonal } \mathrm{T} \text { cells, } \\
\text { proliferation to PHA } \\
>30 \% \text { of normal }\end{array}$ & & $\begin{array}{l}\text { Unpublished } \\
\text { data }\end{array}$ \\
\hline c. $512 \mathrm{C}>\mathrm{G}$ & c.insInt $2 b$ & P171R & $27 \mathrm{y}$ & $\begin{array}{c}\text { Candida species, } \\
\text { HPV, fungal } \\
\text { brain abscess }\end{array}$ & $\begin{array}{l}\text { Neutropenia, } \\
\text { thrombocytopenia }\end{array}$ & $\begin{array}{l}\text { Bilateral } \\
\text { carcinoma } \\
\text { in situ of } \\
\text { nipples }\end{array}$ & $\begin{array}{l}\mathrm{T}^{\mathrm{lo}} \mathrm{B}^{\mathrm{lo}} \mathrm{NK}^{+} \\
\text {abnormal T-cell } \\
\text { proliferation }\end{array}$ & $\begin{array}{l}\text { Mildly } \\
\text { sensitive }\end{array}$ & $\begin{array}{l}\text { Woodbine } \\
\text { e }{\text { et } \mathrm{al}^{24}}^{\text {Wh }}\end{array}$ \\
\hline c. $512 \mathrm{C}>\mathrm{G}$ & $\begin{array}{l}\text { c.1299_1306 } \\
\text { dupAGGATGCT }\end{array}$ & P171R; C436* & $7 \mathrm{y}$ & URI, LRI & $\begin{array}{l}\text { Lymphadenopathy, } \\
\text { granulomatous } \\
\text { inflammation }\end{array}$ & $\begin{array}{l}\text { Hodgkin } \\
\text { lymphoma }\end{array}$ & $\begin{array}{l}\mathrm{T}^{\mathrm{lo}} \mathrm{B}^{-} \mathrm{NK}^{+} \\
\text {absent } \mathrm{Ig} \mathrm{A}\end{array}$ & & 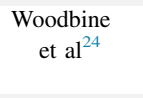 \\
\hline $\begin{array}{c}\text { c.1290_1306 } \\
\text { delACAAAC } \\
\text { CCCAGG } \\
\text { ATGCT }\end{array}$ & $\begin{array}{l}\text { c.1290_1306 } \\
\text { delACAAACCC } \\
\text { CAGGATGCT }\end{array}$ & T432fs*16 & $4 \mathrm{y}$ & LRI, GI & $\begin{array}{l}\text { Cholangitis and } \\
\text { liver cirrhosis } \\
\text { (died at } 16 \mathrm{y} \text { ) }\end{array}$ & & $\begin{array}{l}\mathrm{T}^{\text {lo }} \mathrm{B}^{\text {lo }} \\
\text { hypogam }\end{array}$ & & $\begin{array}{r}\text { Moshous } \\
\text { et } \mathrm{al}^{27}\end{array}$ \\
\hline $\begin{array}{l}\text { c.1353_1359 } \\
\text { delTTGTGAA }\end{array}$ & c.delEx 1-3 & $\mathrm{D} 451 \mathrm{Kfs} * 11$ & Birth & $\begin{array}{l}\text { LRI, Candida } \\
\text { species }\end{array}$ & $\begin{array}{l}\text { AIHA, ITP, cervical } \\
\text { lymphadenopathy }\end{array}$ & $\begin{array}{l}\text { Lymphoma } \\
\quad(9 \mathrm{mo})\end{array}$ & $\begin{array}{l}\mathrm{T}^{-} \mathrm{B}^{-} \mathrm{NK}^{+} \\
\text {monoclonal } \mathrm{IgG}, \\
\text { absent IgA }\end{array}$ & & $\begin{array}{r}\text { Moshous } \\
{\text { et } \mathrm{al}^{27}}^{27}\end{array}$ \\
\hline $\begin{array}{l}\text { c.1353_1359 } \\
\text { delTTGTGAA }\end{array}$ & c.delEx 1-3 & $\mathrm{D} 451 \mathrm{Kfs} * 11$ & Birth & $\begin{array}{l}\text { LRI, Candida } \\
\text { species }\end{array}$ & & Lymphoma & $\begin{array}{l}\mathrm{T}^{\mathrm{lo}} \mathrm{B}^{\mathrm{lo}} \\
\text { hypogam }\end{array}$ & & $\begin{array}{r}\text { Moshous } \\
\text { et } \mathrm{al}^{27}\end{array}$ \\
\hline $\begin{array}{l}\text { c.1353_1359 } \\
\text { delTTGTGAA }\end{array}$ & c.delEx 1-3 & D451Kfs* 11 & $1 \mathrm{y}$ & $\begin{array}{l}\text { URI, LRI, CNS } \\
\quad \text { Toxo }\end{array}$ & & & $\begin{array}{l}\mathrm{T}^{\text {lo }} \mathrm{B}^{-} \mathrm{NK}^{+} \\
\text {hypogam }\end{array}$ & Sensitive & $\begin{array}{r}\text { Moshous } \\
{\text { et } \mathrm{al}^{27}}^{27}\end{array}$ \\
\hline c. 1464 delG & c. $1464 \mathrm{delG}$ & Q488fs & $1 \mathrm{mo}$ & URI, LRI, CMV & $\begin{array}{l}\text { Oral ulcers, } \\
\text { sclerosing } \\
\text { cholangitis, } \\
\text { thrombocytopenia, } \\
\text { hepatospleno- } \\
\text { megaly }\end{array}$ & & $\begin{array}{c}\mathrm{T}^{\text {lo }} \mathrm{B}^{-} \mathrm{NK}^{+} \\
\text {LGL cells, } \\
\text { hypogam }\end{array}$ & & 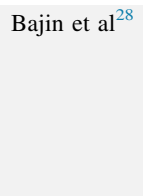 \\
\hline
\end{tabular}

Ab, Antibody; agamma, agammaglobulinemia; $A I H A$, autoimmune hemolytic anemia; $B M$, bone marrow; $C M V$, cytomegalovirus; $C N S$, central nervous system; $G I$, gastrointestinal infection; HPV, human papillomavirus; hypogam, hypogammaglobulinemia; ITP, idiopathic thrombocytopenic purpura; $L G L$, large granular lymphocytes; $L R I$, lower respiratory infections; $M N C$, mononuclear cells; NA, not available; NK, Natural killer; PJP, Pneumocystis jirovecii pneumonia; TB, Tuberculosis; TCR, T-cell receptor; $T^{\text {mat }}$, maternal T cells; Toxo, Toxoplasmosis; TRECs, T-cell receptor excision circles; URI, upper respiratory tract infection; VZV, varicella zoster virus.

\section{Statistical analysis}

Recombination and DNA repair activity levels of ARTEMIS proteins were analyzed with the Mann-Whitney $U$ test. Gene expression levels were compared by using the unpaired 2-tailed Student $t$ test, and a $P$ value of .05 or less was considered significant. Correlation between recombination and DNA repair activity levels was assessed with the Pearson product-moment correlation coefficient ( $r$ ), 2-tailed, 95\% CI.

\section{RESULTS}

\section{Recombination and DNA repair activity in ARTEMIS mutated proteins}

We analyzed recombination and DNA repair activity levels for 22 missense and 6 nonsense mutations, 2 insertions (maximum 8 $\mathrm{bp}$ ), and 11 small deletions (maximum $17 \mathrm{bp}$ ) detected in the DCLRE1C gene in a cohort of 40 ARTEMIS-deficient patients (Table I). 1,3,4,9-11,13,19-28

Chromosomal V(D)J recombination activity was tested in a cellular model, as previously described. ${ }^{14,29}$ V-abl kinasetransformed murine Dclre $1 c^{-/-}$A-MuLV pro-B cells, ${ }^{16}$ hereafter referred to as Dclre $1 c^{-/-}$abl pro-B cells, were engineered with a stable single integration of the pMX-INV GFP cassette flanked by 2 coding RSSs (Fig 1, A, and see Fig E1, B), followed by transduction with a retroviral vector containing WT, mock, or mutagenized $\mathrm{h} D C L R E 1 C$ cDNAs. Subsequently, GFP expression was analyzed as a readout of recombination activity (Fig 1, B), and $\gamma \mathrm{H} 2 \mathrm{AX}$ levels were assessed at 1, 8, 24, and 36 hours after IR with 10 Gy to measure DNA repair activity (Fig 1, $C$ ).

Because of alternative splicing, $16 \mathrm{~h}$ DCLRE1C transcript isoforms are known, where isoforms a, b, and c encode for proteins with 692, 577, and 572 amino acids, respectively. In a preliminary set of experiments, we tested the functional activity of each of these products by transducing Dclrelc ${ }^{-/-}$abl pro-B cells with DCLRE1C transcript isoforms a, b, and c (NM_001033855, NM_022487, and NM_001033858). Only variant a (further referred to as WTa), which encodes for the 692aa canonical sequence, induced high levels of GFP expression, as did the murine Dclrelc transcript isoform a (see Fig E3 in this article's Online Repository at www.jacionline. org). Consequently, isoform WTa was used for mutagenesis 
A

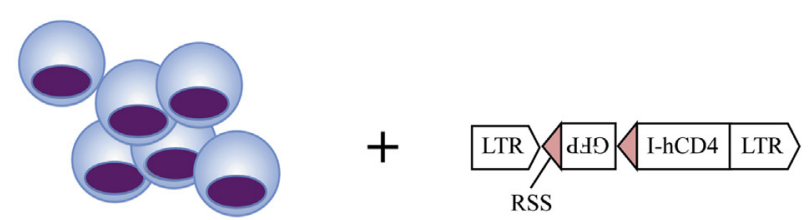

Dclre1c $^{-/}$abl pro-B cells

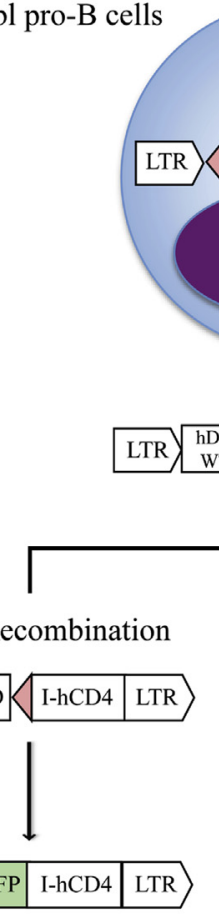

B

V(D)J Recombination

C

DNA Repair
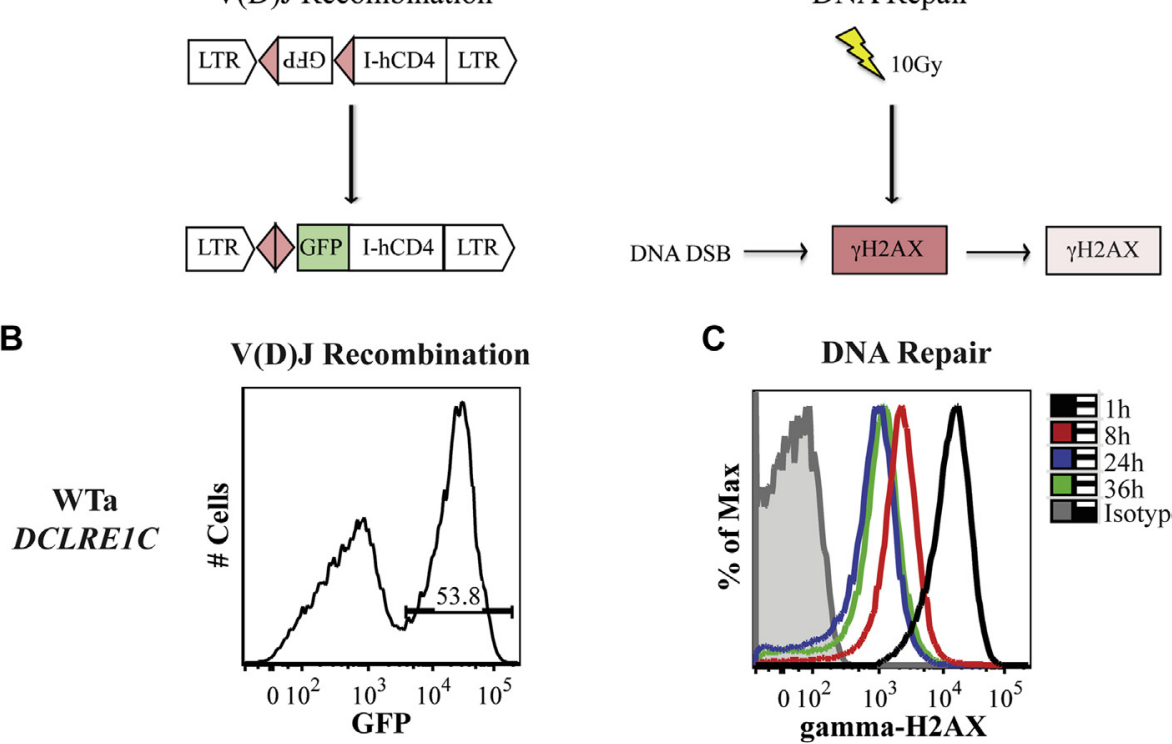

DNA Repair
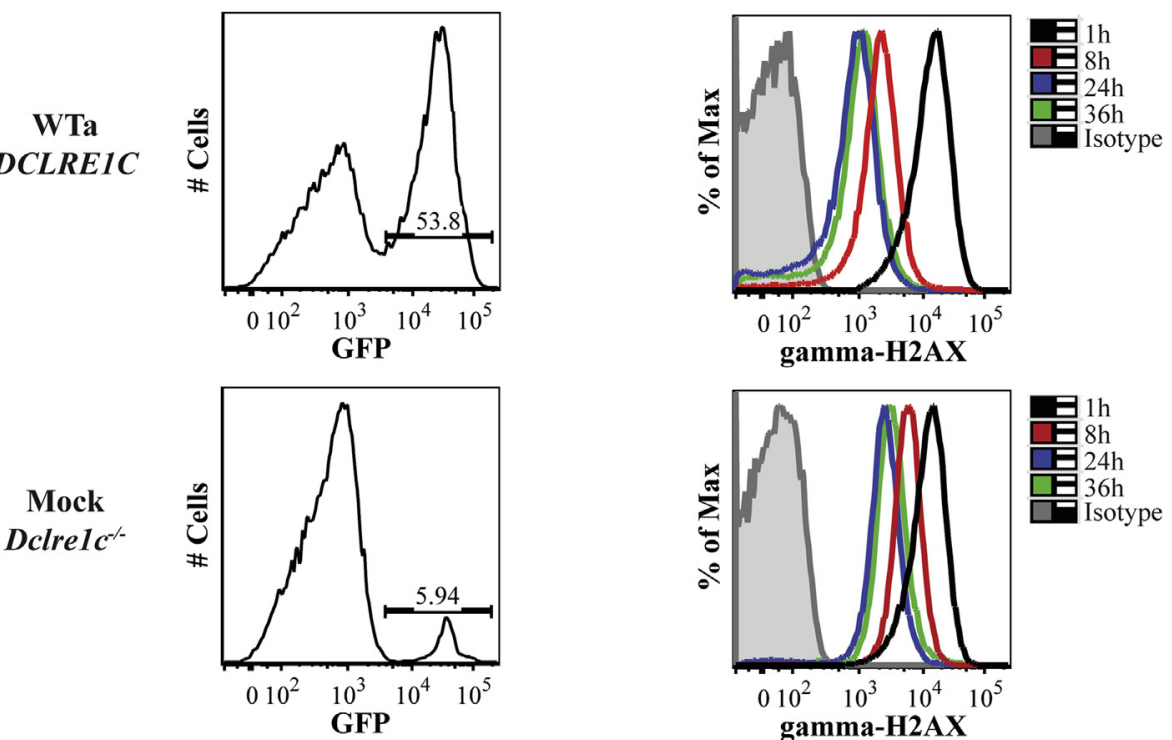

FIG 1. Schematic representation of the experimental outline and readout. A, Dclre $1 c^{-/-}$abl pro-B cells were retrovirally engineered with a single construct containing an inverted GFP cassette flanked by 2 RSSs and the hCD4 sequence for positive selection. Subsequently, cells were transduced with a second construct containing either WT or mutated $\mathrm{h} D C L R E 1 C$ (isoform a) and the $\mathrm{h} C D 2$ sequence. Sufficient targeting of RSS by the Rag1/Rag2 complex and completion of the recombination process, which involves ARTEMIS, allows the GFP cassette to flip into sense orientation. B, GFP expression can be used for quantification of $\mathrm{V}(\mathrm{D}) \mathrm{J}$ recombination activity in cells expressing both vectors $\left(\mathrm{CD} 4^{+} \mathrm{CD} 2^{+}\right)$. C, To assess DNA repair activity, cells were irradiated with $10 \mathrm{~Gy}$, and $\gamma \mathrm{H} 2 \mathrm{AX}$ dephosphorylation was quantified by means of flow cytometry at $1,8,24$, and 36 hours in cells expressing the DCLRE1C-hCD2 vector. The difference in GFP expression and downregulation of $\gamma \mathrm{H} 2 \mathrm{AX}$ is shown for Dclre $1 c^{-/-}$abl pro-B cells transduced with WTa DCLRE1C or a mock plasmid, respectively. LTR, Long terminal repeat. 


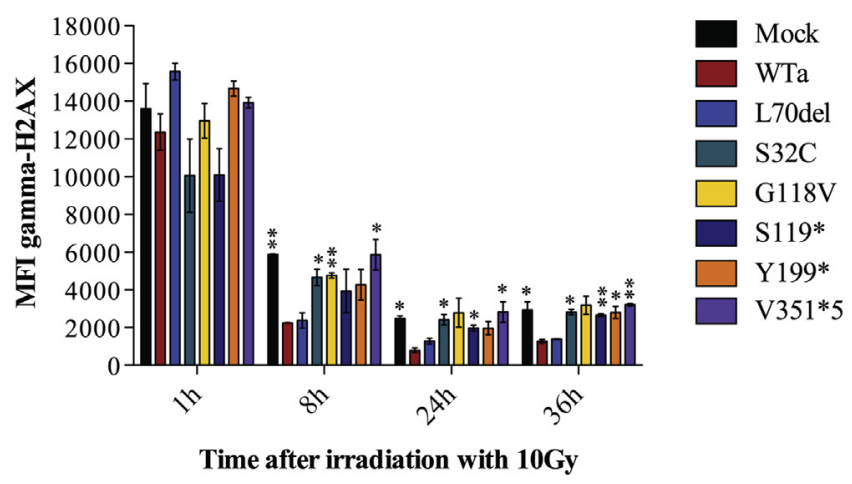

FIG 2. DNA repair activities were analyzed in Dclre $1 c^{-1-}$ abl pro-B cells blocked in G0/G1 cell-cycle phases. MFIs for $\gamma \mathrm{H} 2 \mathrm{AX}$ at 1, 8, 24, and 36 hours after irradiation with $10 \mathrm{~Gy}$ are shown for one representative experiment testing 6 ARTEMIS mutants compared with WTa and mock-transduced Dclre $1 c^{-/-}$abl pro-B cells. Error bars indicate SDs. ${ }^{*} P \leq .05$ and ${ }^{*} P \leq .01$.

experiments. Expression of DCLRE1C transcript was confirmed by using quantitative PCR (see Fig E4 in this article's Online Repository at www.jacionline.org).

In contrast to what was observed with $\mathrm{Ragl}^{-/-}$abl pro-B cells, ${ }^{14}$ minimal levels of GFP expression were observed in mock-transduced Dclrelc $c^{-/-}$abl pro-B cells (Fig 1, B), indicating occurrence of construct rejoining in a small fraction of cells, even in the absence of the endogenous Artemis protein.

Although DNA breaks are repaired over time, progressive dephosphorylation of the $\mathrm{H} 2 \mathrm{AX}$ histone occurs. Because ARTEMIS is only required for processing of a small fraction of DNA breaks repaired in a slow-kinetic pathway, ${ }^{7}$ differences in $\gamma \mathrm{H} 2 \mathrm{AX}$ expression in Dclrelc ${ }^{-/-}$abl pro-B cells expressing WT or mutant ARTEMIS constructs can be best appreciated at later time points, such as 24 to 36 hours (Fig 2).

\section{Correlation between functional activity and clinical phenotype}

ARTEMIS mutants were divided into 2 major subgroups: (1) missense mutations and in-frame deletions; and, (2) frameshift mutations. When recombination and DNA repair activity were plotted against the location of the individual mutations along the protein, significant variability of protein function was observed for missense/in-frame mutations affecting the $\beta$-lactamase or the $\beta$-CASP domain, including missense mutations within the same codon (eg, T134A and T134R or D165N and D165V; Fig 3, $A$ and $B$, and Table II). Frameshift mutations disrupting these domains almost completely abrogated ARTEMIS function. By contrast, frameshift mutations disrupting the $\mathrm{C}$-terminus consistently retained high activity levels when expressed in Dclrelc ${ }^{-/-}$abl pro-B cells (Table II), which is consistent with the less severe phenotype in patients harboring these mutations.

Although there was a trend for slightly higher DNA repair activities, particularly in the $\beta$-CASP domain, recombination activities correlated well with DNA repair activities $\left(r_{b \text {-lact }}=\right.$ $0.964, P<.001 ; r_{b \text {-CASP }}=0.818, P=.001 ; r_{C \text {-term }}=0.968$, $P<.001$; Fig 3, $C-E$ ). This might reflect the notion that ARTEMIS plays a more critical role in $\mathrm{V}(\mathrm{D}) \mathrm{J}$ recombination than in NHEJ-mediated DNA repair.

Patients were divided into 2 cohorts to correlate recombination and DNA repair activity levels of mutated ARTEMIS proteins with the clinical presentation: (1) typical SCID and (2) the milder atypical presentation (leaky SCID). The definition of SCID was done in accordance with Primary Immune Deficiency Treatment Consortium criteria, ${ }^{15}$ which included a T-cell count of less than $300 / \mu \mathrm{L}$, the presence of maternal T-cell engraftment, or both. In cases in which this information was not available, we assumed the interpretation of the authors of the original report.

As expected, most of the patients in the SCID group presented with severe and opportunistic infections early in life; by contrast, patients with leaky SCID often had autoimmune cytopenias $(6 / 15)$, other autoimmune manifestations $(2 / 15)$, lymphoproliferation $(5 / 15)$, or malignancies in the form of lymphoma (4/15) or squamous cell carcinoma (1/15, Table I). Two patients in this group had mutations affecting the DCLRE1C translation initiation site, one presenting with OS and the other with leaky SCID, but without skin manifestations.

Activity levels of the mutated proteins were analyzed in patients with SCID versus leaky SCID to attempt correlation with the clinical phenotype. For patients with compound heterozygous mutations, we considered the mutant with the higher activity level. As shown in Fig 4, $A$ and $B$, both recombination and DNA repair activity levels were significantly higher for mutations observed in patients with leaky SCID $(P \leq .001)$. However, although robust levels of protein function were uniformly recorded for mutations associated with leaky SCID, significant variability was observed for mutations associated with SCID. Importantly, patients with leaky SCID were either homozygous for frameshift mutations affecting the C-terminus and that retained residual activity or were compound heterozygous for a hypomorphic mutation (or a putative polymorphism) and a loss-of-function allele (Fig 4, C).

\section{Correlation of predicted pathogenicity with functional activity}

To predict the pathogenicity of the DCLRE1C mutations analyzed, we used the online bioinformatics tools PolyPhen- $2^{30}$ and SIFT $^{31}$ (see Table E1 in this article's Online Repository at www.jacionline.org).

All but 3 genetic variants (G153R, T71P, and P171R) were predicted as disease causing by both tools. The variant $\mathrm{P} 171 \mathrm{R}$ is a known polymorphism and has been reported before. ${ }^{24}$ All 3 variants showed high activity levels in our study.

To investigate the frequency of putatively damaging DCLRE1C genetic variants in the general population, we analyzed data of the Exome Aggregation Consortium (ExAC) of the Broad Institute (Cambridge, Mass; http://exac.broadinstitute.org; December 2014), which includes whole-exome sequencing data from more than 60,000 subjects. Most of the mutations reported in patients with SCID or leaky SCID and analyzed in this article were not reported in the ExAC database. However, 2 of them (G153R and P171R) were reported at rather high frequencies (0.01 and 0.09). Furthermore, homozygosity for these variants was demonstrated in a considerable number of subjects (12 and 612 , respectively) in the ExAC database (see Table E1). The fully normal VDJ activity of these variants is consistent with their polymorphism status.

The mutations M1T and M1V, which had been identified in compound heterozygous patients presenting with OS and leaky SCID (unpublished data), ${ }^{13}$ were predicted by Mutation T@ ster $^{32}$ to use an alternative translation initiation site 7 amino acids 
A
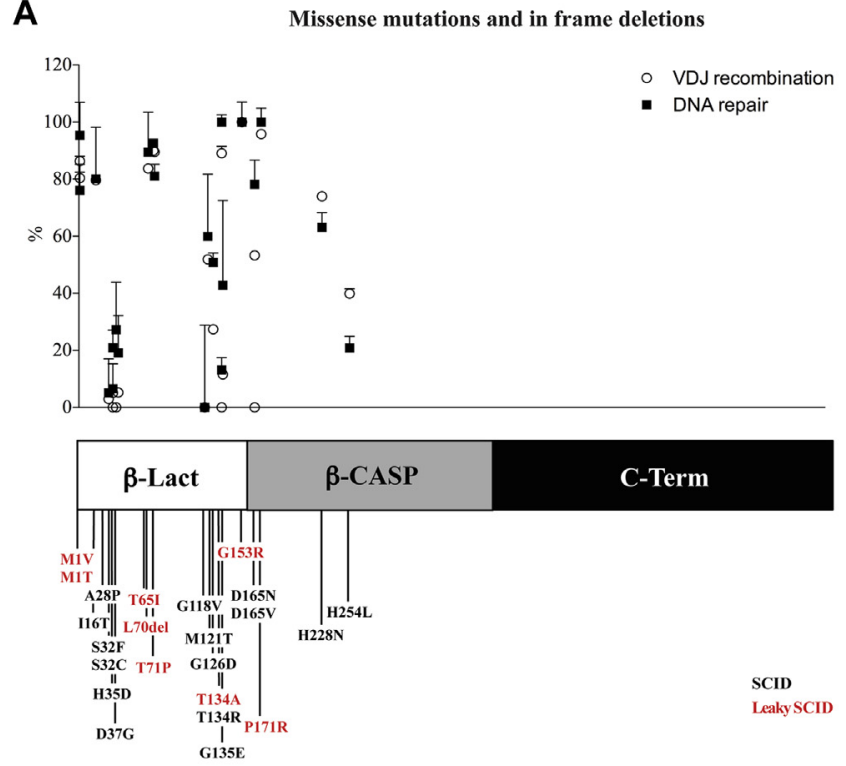

C

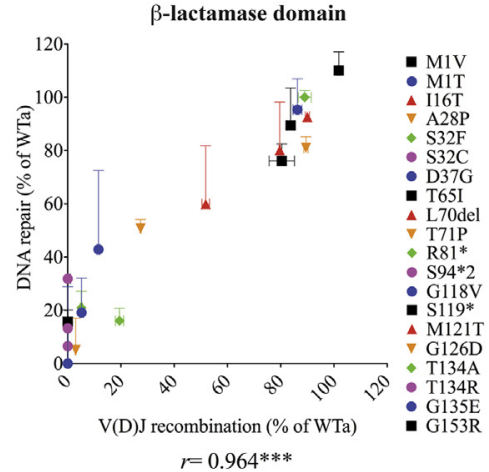

B

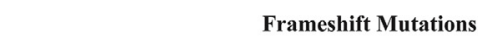

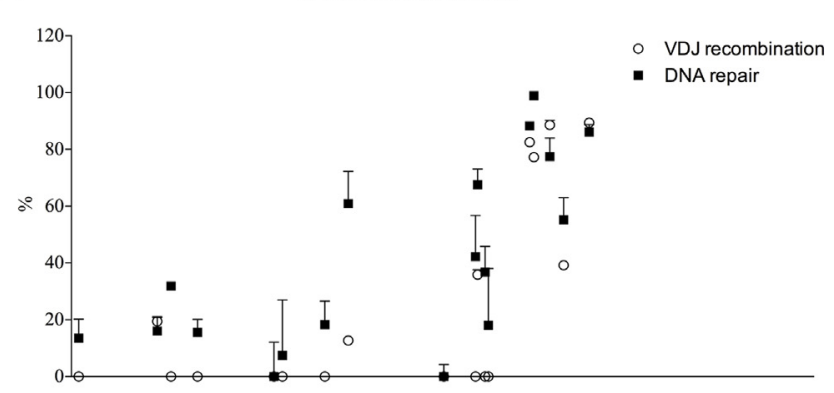

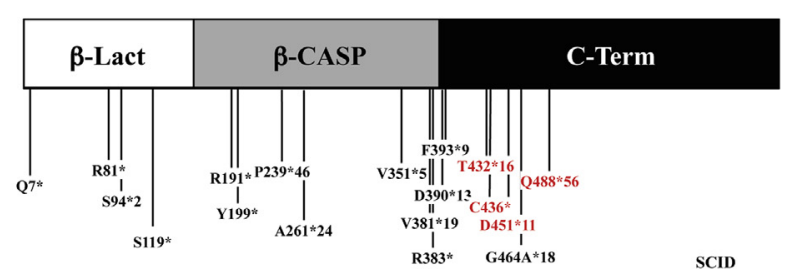

LCID

D

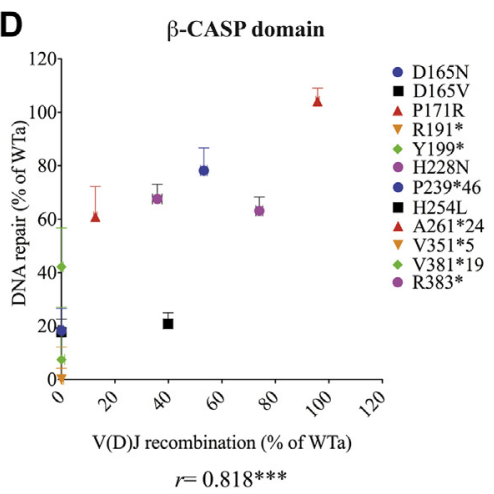

E

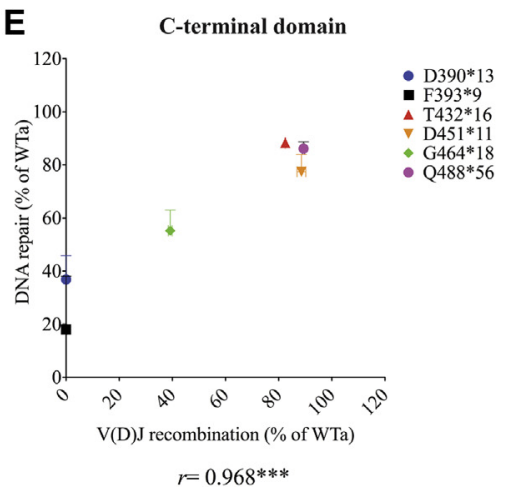

FIG 3. Correlation of $V(D) J$ recombination with DNA repair activities. $\mathbf{A}$ and $\mathbf{B}$, Recombination and DNA repair activity levels of 41 genetic DCLRE1C variants were studied in 23 missense mutations and in-frame deletions (Fig 3, A) and 18 frameshift mutations (Fig 3, B) affecting various domains: the metallo- $\beta$-lactamase domain (amino acids 1-155), the $\beta$-CASP domain (amino acids 156-385), and the C-terminal region (amino acids 386-692). ${ }^{5}$ C-E, $\mathrm{V}(\mathrm{D}) \mathrm{J}$ recombination activity levels of mutations affecting the $\beta$-lactamase (Fig 3,C), $\beta$-CASP (Fig 3, D), and C-terminal (Fig 3,E) domains of the protein are plotted against DNA repair activities. Activity levels are expressed as percentages of WTa performance. Error bars indicate SDs. ${ }^{* *} P \leq .001$.

downstream. We observed high activity levels for both mutants in our system, suggesting residual function.

\section{Protein overexpression restores activity of hypomorphic ARTEMIS variants}

A feature of the cellular platform described here is that retrovirus-mediated transduction typically results in generation of a population of cells harboring a different number of copies of DCLRE1C cDNA. The number of vector copies in the pool of unselected cells harboring these mutations consistently ranged between 4 and 8 per cell (data not shown). To investigate whether high levels of activity could reflect protein overexpression, we selected the hypomorphic mutants M1T and T432*16 and the polymorphism P171R, all of which showed high recombination and DNA repair activities when tested in bulk culture of Dclrelc ${ }^{-/-}$abl pro-B cells $(80 \%$ to $100 \%$ of WT DCLRE1C, Table II). On limiting dilution subcloning of transduced Dclrelc ${ }^{-i-}$ abl pro-B cells harboring these mutations, we selected clones with more than 6 copies of vector and compared their activity levels with those of clones with 2 vector copies (see Fig E5 in this article's Online Repository at www. jacionline.org). Both the recombination and DNA repair activities of the M1T and T432*16 mutants were significantly lower in clones harboring 2 vector copies than in those with 6 copies. By contrast, high activity was observed for P171R, even in clones with 2 copies of this variant (Fig 5). These data are consistent with P171R being a polymorphism. Furthermore, they indicate that overexpression can partially restore the functional activity of hypomorphic ARTEMIS mutants.

\section{DISCUSSION}

The endonuclease and exonuclease ARTEMIS has a crucial function in opening the hairpin-sealed coding ends of $\mathrm{V}, \mathrm{D}$, and $\mathrm{J}$ elements during $\mathrm{V}(\mathrm{D}) \mathrm{J}$ recombination in developing $\mathrm{T}$ and $\mathrm{B}$ lymphocytes ${ }^{3}$ and in processing overhangs that occur in a small fraction of DNA double-strand breaks. ${ }^{8}$ The severity of 
TABLE II. Recombination and DNA repair activity levels of DCLRE1C mutated products

\begin{tabular}{|c|c|c|c|c|c|}
\hline \multicolumn{2}{|c|}{ Mutations in DCLRE1C } & \multicolumn{4}{|c|}{ Activity levels in \% of WT activity } \\
\hline \multirow[b]{2}{*}{ Genomic } & \multirow[b]{2}{*}{ Protein } & \multicolumn{2}{|c|}{ Recombination } & \multicolumn{2}{|c|}{ DNA repair (36 $\mathrm{h}$ after IR) } \\
\hline & & Mean & SD & Mean & SD \\
\hline \multicolumn{6}{|l|}{ Metallo- $\beta$-lactamase domain } \\
\hline c. $1 \mathrm{~A}>\mathrm{G}$ & M1V & 86.32 & 1.67 & 95.35 & 11.60 \\
\hline c. $2 \mathrm{~T}>\mathrm{C}$ & M1T & 80.41 & 4.77 & 76.04 & 6.43 \\
\hline c. $19 \mathrm{C}>\mathrm{T}$ & Q7* & 0.00 & 0.35 & 13.52 & 6.66 \\
\hline c. $95 \mathrm{C}>\mathrm{T}$ & $\mathrm{S} 32 \mathrm{~F}$ & 5.14 & 0.34 & 20.95 & 6.17 \\
\hline c. $95 \mathrm{C}>\mathrm{G}$ & $\mathrm{S} 32 \mathrm{C}$ & 0.00 & 0.40 & 6.56 & 8.73 \\
\hline c. $103 \mathrm{C}>\mathrm{G}$ & $\mathrm{H} 35 \mathrm{D}$ & 0.00 & 0.30 & 27.29 & 16.57 \\
\hline c. $110 A>G$ & D37G & 5.24 & 0.65 & 19.15 & 13.04 \\
\hline c. $194 \mathrm{C}>\mathrm{T}$ & T65I & 83.75 & 1.32 & 89.45 & 14.05 \\
\hline c.207_209delGTT & L70del & 90.01 & 0.77 & 92.63 & 0.96 \\
\hline c. $362 \mathrm{~T}>\mathrm{C}$ & M121T & 51.87 & 1.45 & 59.88 & 21.87 \\
\hline c. $377 \mathrm{G}>\mathrm{A}$ & G126D & 27.40 & 0.21 & 50.80 & 3.31 \\
\hline c. $400 \mathrm{~A}>\mathrm{G}$ & $\mathrm{T} 134 \mathrm{~A}$ & 89.04 & 2.43 & 111.18 & 2.53 \\
\hline c. $401 \mathrm{C}>\mathrm{G}$ & $\mathrm{T} 134 \mathrm{R}$ & 0.00 & 0.44 & 13.21 & 4.25 \\
\hline c. $404 \mathrm{G}>\mathrm{A}$ & G135E & 11.57 & 0.54 & 42.84 & 29.68 \\
\hline c. $457 \mathrm{G}>\mathrm{A}$ & G153R & 101.82 & 0.45 & 110.04 & 7.03 \\
\hline \multicolumn{6}{|l|}{$\beta$-CASP domain } \\
\hline c. $493 \mathrm{G}>\mathrm{A}$ & D165N & 53.26 & 1.28 & 78.20 & 8.48 \\
\hline c. $494 \mathrm{~A}>\mathrm{T}$ & $\mathrm{D} 165 \mathrm{~V}$ & 0.00 & 0.62 & 17.71 & 4.91 \\
\hline c. $512 \mathrm{C}>\mathrm{G}$ & P171R & 95.79 & 0.62 & 104.12 & 4.91 \\
\hline c. $571 \mathrm{C}>\mathrm{T}$ & R191* & 0.00 & 0.87 & 0.00 & 12.11 \\
\hline c. $597 \mathrm{C}>\mathrm{A}$ & Y199* & 0.00 & 1.21 & 7.46 & 19.56 \\
\hline c.1167_1168insAG & $\mathrm{D} 390 * 13$ & 0.00 & 0.30 & 36.84 & 9.00 \\
\hline c.1179delT & $\mathrm{F} 393 * 9$ & 0.00 & 0.42 & 18.07 & 19.99 \\
\hline c.1290_1306del17 & $\mathrm{T} 432 * 16$ & 82.49 & 0.12 & 88.29 & 1.09 \\
\hline c.1299_1306dupAGGATGCT & C436* & 77.26 & 0.42 & 98.89 & 1.26 \\
\hline c.1353_1359delTTGTGAA & $\mathrm{D} 451 * 11$ & 88.57 & 1.64 & 77.43 & 6.53 \\
\hline c.1391_1395delGAATC & $\mathrm{G} 464 * 18$ & 39.21 & 0.71 & 55.22 & 7.76 \\
\hline 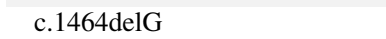 & $\mathrm{Q} 488 * 56$ & 89.38 & 0.46 & 86.14 & 2.59 \\
\hline
\end{tabular}

ARTEMIS deficiency depends on the amount of residual nuclease activity. Although lack of protein expression or function completely abrogates T- and B-cell development, hypomorphic mutant proteins allow $\mathrm{V}(\mathrm{D}) \mathrm{J}$ recombination, although with reduced efficacy. This results in a milder immunodeficiency but also in susceptibility to autoimmunity, lymphoproliferation, and malignancy. In this regard the clinical phenotype of leaky ARTEMIS deficiency resembles that observed in patients with hypomorphic RAG1 or RAG2 defects. ${ }^{33}$ To gain more insight into genotype-phenotype correlation in ARTEMIS deficiency, we analyzed recombination and DNA repair activity in a large series of naturally occurring ARTEMIS mutants and correlated these results with the clinical phenotype. To this purpose, we used a similar cellular platform to the one we have recently reported to investigate genotype-proteotype-phenotype correlation in patients with RAG1 deficiency. ${ }^{14}$ Importantly, an advantage of the Dclrelc ${ }^{-/-}$abl pro-B-cell system is that it allows simultaneous analysis of recombination activity and DNA repair.

Although ARTEMIS plays a critical role in V(D)J recombination, its major function as a component of the NHEJ pathway of DNA repair is to process specific DNA double-strand breaks, which are repaired in a slow-kinetic process. By analyzing the kinetics of H2AX histone dephosphorylation in pro-B-cell lines expressing mutant (or WT) ARTEMIS at various time points after exposure to IR, we observed different levels of DNA repair activity for the various mutants analyzed, with good correlation with the data observed in the recombination assay. However, 
A

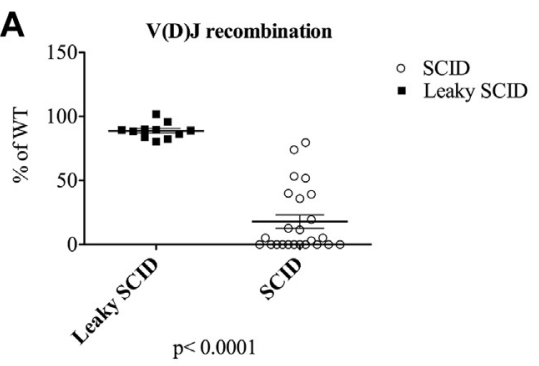

B

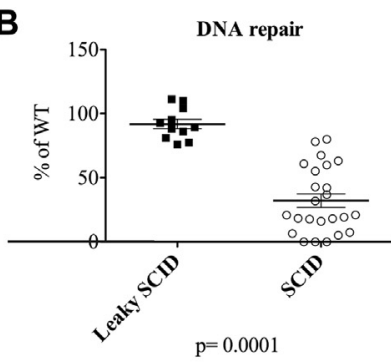

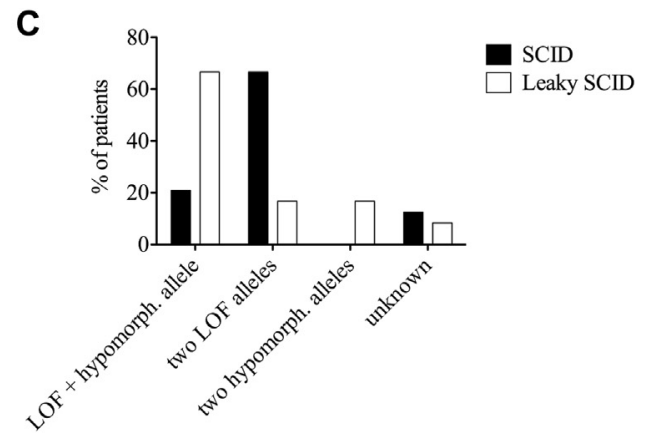

FIG 4. A and B, Activity levels for recombination (Fig 4, A) and DNA repair (Fig 4, B) of the mutations with the highest activity (in case of compound heterozygosity) found in patients presenting with SCID and leaky SCID are shown $(P<.0001$ and $P=.0001)$. C, Percentages of patients heterozygous or homozygous for a loss-of-function or hypomorphic DCLRE1C allele are shown for patients with SCID and those with leaky SCID. LOF, Loss of function.

A

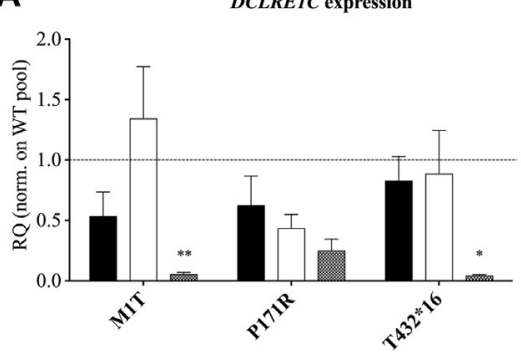

B

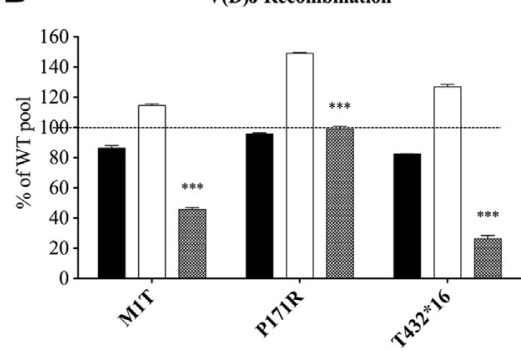

C

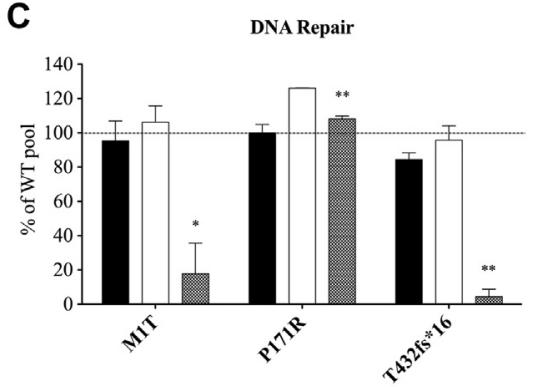

2 vector copies

Pool with variable vector copies

$\square \geq 6$ vector copies

FIG 5. Recombination and DNA repair activity levels of hypomorphic DCLRE $1 C$ variants with various vector copy numbers. Expression levels of 2 hypomorphic DCLRE1C variants and 1 polymorphism were titrated by varying vector copy numbers to 6 or greater or 2. A, Expression of human DCLRE1C was assessed by means of quantitative PCR in cDNA samples and normalized to WTa (indicated by dashed line). B and C, Activity levels for $\mathrm{V}(\mathrm{D}) \mathrm{J}$ recombination (Fig $5, B$ ) and DNA repair (Fig 5, C) were compared between 6 or more or 2 vector copies or the pool containing variable copy numbers per cell. Error bars indicate SDs. ${ }^{*} P \leq .05$, ${ }^{* *} P \leq .01$, and ${ }^{* * *} P \leq .001$.

slightly higher levels of DNA repair than of recombination were observed in mutants with absent or low recombination activity, which was particularly the case for mutations affecting the $\beta$-CASP domain. It has been proposed that the $\beta$-CASP domain participates with the $\beta$-lactamase region in forming the catalytic core of ARTEMIS. ${ }^{5}$ Our findings suggest that ARTEMIS might play a less critical role in DNA repair than in $V(D) J$ recombination.

Consistent with previous observations, ${ }^{12,25}$ we found that mutations affecting highly conserved residues in the catalytically active $\beta$-lactamase or $\beta$-CASP domains completely abrogate function and are associated with typical features of SCID. Mutations affecting other residues in the same domains can cause conformational changes that can variably affect protein function, as indicated by heterogeneous levels of activity, even for missense mutations involving the same codon.

Mutations disrupting the $\mathrm{C}$-terminus take a special position. In contrast to the $\beta$-lactamase and $\beta$-CASP domain, this region is dispensable for the catalytic function ${ }^{5}$ but plays a critical role in regulation of $\mathrm{V}(\mathrm{D}) \mathrm{J}$ recombination and DNA repair through interaction with DNA protein kinase catalytic subunit and DNA Ligase $4 .^{6,34}$ It has recently been reported that ARTEMIS also interacts with PAX transactivation domain-interacting protein (PTIP), a BRCA1 C terminus (BRCT)-domain containing effector protein in the p53-binding protein 1 (53BP1) pathway that antagonizes the homologous recombination DNA repair pathway. ${ }^{35}$ The importance of this region for genomic stability has been studied in detail in a mouse model harboring a C-terminal 7-nt deletion resulting in a frameshift mutation at D449 (corresponding to $\mathrm{D} 451 * 11$ in human subjects). ${ }^{36}$ This mutation was shown to cause aberrant intrachromosomal and interchromosomal $\mathrm{V}(\mathrm{D}) \mathrm{J}$ joining events predisposing to lymphoma. ${ }^{37}$ Five of 8 patients reported with deletions in this region presented with leaky SCID, 4 had features of autoimmunity, and 2 had EBVassociated lymphomas. ${ }^{4,20,26-28}$ Except for 2 mutations affecting the most proximal part of the C-terminal domain and reported in patients with SCID, we observed very high activity levels for all other truncating C-terminal mutations. Interestingly, 50\% of the patients with leaky SCID and C-terminal mutations were homozygous for such defects. This contrasts with the observation that the remainder of the patients with leaky SCID carried a hypomorphic missense mutation on one allele and a deletion on the second allele.

Our system allows us to assess functional activity of ARTEMIS mutated proteins on an intrachromosomal substrate in a relevant cell type (pro-B cells), which represents a stage of B-cell development in which V(D)J recombination occurs physiologically. Other approaches to test ARTEMIS activity are based on cotransfection of a reporter construct and RAG1 and RAG2 expression plasmids into the cytoplasm of ARTEMIS mutated fibroblast cell lines. ${ }^{5,12}$ However, it is important to mention that 
none of the cellular platforms available allow us to fully model functional activities as they occur in patients. In particular, in the cellular platform described here, ARTEMIS expression is driven under a viral promoter and influenced by random genomic integration and by the number of vector copies. All of these factors can contribute to variable expression, including overexpression. To adjust for this limitation, we normalized mutant activities to WT activity and subtracted background activities obtained in mock-transduced cells. Furthermore, to assess the effect of protein overexpression on recombination and DNA repair activity, we performed limiting dilution analysis of vector copy numbers. By titrating the expression levels of the hypomorphic mutations M1T and T432*16, we observed that overexpression was associated with improved functional activity. This was not the case for the P171R variant, for which high levels of activity were consistently observed, even in clones harboring only 2 vector copies.

Our data differ from previous observations that had reported that the P171R variant had significantly lower than normal activity, which could be partially restored by increased product expression. ${ }^{24}$ Importantly, the observation that overexpression of the M1T and T432*16 mutants was associated with improved functional activity in Dclrelc $c^{-1-}$ abl pro-B cells raises the interesting hypothesis that novel therapeutic approaches aimed at enhancing gene transcription might be efficacious in patients with hypomorphic DCLRE1C mutations. However, overexpression of DCLRE $1 C$ has also been associated with cytotoxicity, ${ }^{38}$ suggesting that regulated control of increased expression might be necessary for therapeutic purposes.

In summary, we report on a cellular platform that permits us to analyze both recombination activity and DNA double-strand break repair function of naturally occurring ARTEMIS mutations. Good correlation was observed between the functional activity of the mutated protein and the clinical phenotype of affected patients. Use of this cellular system might allow us to assess the possible disease-causing role of novel DCLRE1C genetic variants identified in patients. Finally, the observation that overexpression of hypomorphic mutants might significantly rescue function opens the way to possible future therapeutic interventions based on modulation of gene expression for patients with ARTEMIS deficiency.

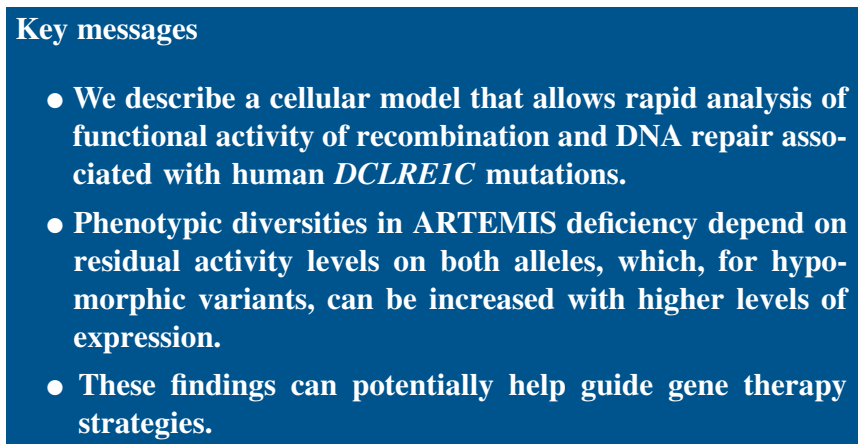

\section{REFERENCES}

1. Le Deist F, Poinsignon C, Moshous D, Fischer A, de Villartay JP. Artemis sheds new light on V(D)J recombination. Immunol Rev 2004;200:142-55.

2. Biffi A, Montini E, Lorioli L, Cesani M, Fumagalli F, Plati T, et al. Lentiviral hematopoietic stem cell gene therapy benefits metachromatic leukodystrophy. Science 2013;341:1233158.
3. Ma Y, Pannicke U, Schwarz K, Lieber MR. Hairpin opening and overhang processing by an Artemis/DNA-dependent protein kinase complex in nonhomologous end joining and V(D)J recombination. Cell 2002;108:781-94.

4. van der Burg M, Verkaik NS, den Dekker AT, Barendregt BH, Pico-Knijnenburg I, Tezcan I, et al. Defective Artemis nuclease is characterized by coding joints with microhomology in long palindromic-nucleotide stretches. Eur J Immunol 2007;37: 3522-8.

5. Poinsignon C, Moshous D, Callebaut I, de Chasseval R, Villey I, de Villartay JP. The metallo-beta-lactamase/beta-CASP domain of Artemis constitutes the catalytic core for V(D)J recombination. J Exp Med 2004;199:315-21.

6. Malu S, De Ioannes P, Kozlov M, Greene M, Francis D, Hanna M, et al. Artemis Cterminal region facilitates $\mathrm{V}(\mathrm{D}) \mathrm{J}$ recombination through its interactions with DNA Ligase IV and DNA-PKcs. J Exp Med 2012;209:955-63.

7. Riballo E, Kuhne M, Rief N, Doherty A, Smith GC, Recio MJ, et al. A pathway of double-strand break rejoining dependent upon ATM, Artemis, and proteins locating to gamma-H2AX foci. Mol Cell 2004;16:715-24.

8. Darroudi F, Wiegant W, Meijers M, Friedl AA, van der Burg M, Fomina J, et al Role of Artemis in DSB repair and guarding chromosomal stability following exposure to ionizing radiation at different stages of cell cycle. Mutat Res 2007; 615:111-24.

9. Moshous D, Callebaut I, de Chasseval R, Corneo B, Cavazzana-Calvo M, Le Deist F, et al. Artemis, a novel DNA double-strand break repair/V(D)J recombination protein, is mutated in human severe combined immune deficiency. Cell 2001; 105:177-86.

10. Li L, Moshous D, Zhou Y, Wang J, Xie G, Salido E, et al. A founder mutation in Artemis, an SNM1-like protein, causes SCID in Athabascan-speaking Native Americans. J Immunol 2002;168:6323-9.

11. Pannicke U, Honig M, Schulze I, Rohr J, Heinz GA, Braun S, et al. The most frequent DCLRE1C (ARTEMIS) mutations are based on homologous recombination events. Hum Mutat 2010;31:197-207.

12. Pannicke U, Ma Y, Hopfner KP, Niewolik D, Lieber MR, Schwarz K. Functional and biochemical dissection of the structure-specific nuclease ARTEMIS. EMBO J 2004;23:1987-97.

13. Ege M, Ma Y, Manfras B, Kalwak K, Lu H, Lieber MR, et al. Omenn syndrome due to ARTEMIS mutations. Blood 2005;105:4179-86.

14. Lee YN, Frugoni F, Dobbs K, Walter JE, Giliani S, Gennery AR, et al. A systematic analysis of recombination activity and genotype-phenotype correlation in human recombination-activating gene 1 deficiency. J Allergy Clin Immunol 2014;133:1099-108.

15. Shearer WT, Dunn E, Notarangelo LD, Dvorak CC, Puck JM, Logan BR, et al Establishing diagnostic criteria for severe combined immunodeficiency disease (SCID), leaky SCID, and Omenn syndrome: the Primary Immune Deficiency Treatment Consortium experience. J Allergy Clin Immunol 2014;133:1092-8.

16. Bredemeyer AL, Helmink BA, Innes CL, Calderon B, McGinnis LM, Mahowald GK, et al. DNA double-strand breaks activate a multi-functional genetic program in developing lymphocytes. Nature 2008;456:819-23.

17. De Ravin SS, Cowen EW, Zarember KA, Whiting-Theobald NL, Kuhns DB, Sandler NG, et al. Hypomorphic Rag mutations can cause destructive midline granulomatous disease. Blood 2010;116:1263-71.

18. Martin OA, Ivashkevich A, Choo S, Woodbine L, Jeggo PA, Martin RF, et al. Statistical analysis of kinetics, distribution and co-localisation of DNA repair foci in irradiated cells: cell cycle effect and implications for prediction of radiosensitivity. DNA Repair (Amst) 2013;12:844-55.

19. Lagresle-Peyrou C, Benjelloun F, Hue C, Andre-Schmutz I, Bonhomme D, Forveille M, et al. Restoration of human B-cell differentiation into NOD-SCID mice engrafted with gene-corrected CD34+ cells isolated from Artemis or RAG1-deficient patients. Mol Ther 2008;16:396-403.

20. Musio A, Marrella V, Sobacchi C, Rucci F, Fariselli L, Giliani S, et al. Damaging-agent sensitivity of Artemis-deficient cell lines. Eur J Immunol 2005; 35:1250-6.

21. Lee PP, Woodbine L, Gilmour KC, Bibi S, Cale CM, Amrolia PJ, et al. The many faces of Artemis-deficient combined immunodeficiency-two patients with DCLRE1C mutations and a systematic literature review of genotype-phenotype correlation. Clin Immunol 2013;149:464-74.

22. Noordzij JG, Verkaik NS, van der Burg M, van Veelen LR, de Bruin-Versteeg S, Wiegant W, et al. Radiosensitive SCID patients with Artemis gene mutations show a complete B-cell differentiation arrest at the pre-B-cell receptor checkpoint in bone marrow. Blood 2003;101:1446-52.

23. Evans PM, Woodbine L, Riballo E, Gennery AR, Hubank M, Jeggo PA. Radiationinduced delayed cell death in a hypomorphic Artemis cell line. Hum Mol Genet 2006; $15: 1303-11$.

24. Woodbine L, Grigoriadou S, Goodarzi AA, Riballo E, Tape C, Oliver AW, et al. An Artemis polymorphic variant reduces Artemis activity and confers cellular radiosensitivity. DNA Repair (Amst) 2010;9:1003-10. 
25. de Villartay JP, Shimazaki N, Charbonnier JB, Fischer A, Mornon JP, Lieber MR, et al. A histidine in the beta-CASP domain of Artemis is critical for its full in vitro and in vivo functions. DNA Repair (Amst) 2009;8:202-8.

26. Kobayashi N, Agematsu K, Sugita K, Sako M, Nonoyama S, Yachie A, et al. Nove Artemis gene mutations of radiosensitive severe combined immunodeficiency in Japanese families. Hum Genet 2003;112:348-52.

27. Moshous D, Pannetier C, Chasseval Rd Rd, Deist Fl Fl, Cavazzana-Calvo M, Romana S, et al. Partial T and B lymphocyte immunodeficiency and predisposition to lymphoma in patients with hypomorphic mutations in Artemis. J Clin Invest 2003;111:381-7.

28. Bajin IY, Ayvaz DC, Unal S, Ozgur TT, Cetin M, Gumruk F, et al. Atypical combined immunodeficiency due to Artemis defect: a case presenting as hyperimmunoglobulin M syndrome and with LGLL. Mol Immunol 2013;56:354-7.

29. Bredemeyer AL, Sharma GG, Huang CY, Helmink BA, Walker LM, Khor KC, et al. ATM stabilizes DNA double-strand-break complexes during V(D)J recombination. Nature 2006;442:466-70.

30. Adzhubei IA, Schmidt S, Peshkin L, Ramensky VE, Gerasimova A, Bork P, et al. A method and server for predicting damaging missense mutations. Nat Methods 2010; 7:248-9.

31. Kumar P, Henikoff S, Ng PC. Predicting the effects of coding non-synonymous variants on protein function using the SIFT algorithm. Nat Protoc 2009;4:1073-81.
32. Schwarz JM, Cooper DN, Schuelke M, Seelow D. MutationTaster2: mutation prediction for the deep-sequencing age. Nat Methods 2014;11:361-2.

33. Schuetz C, Huck K, Gudowius S, Megahed M, Feyen O, Hubner B, et al. An immunodeficiency disease with RAG mutations and granulomas. N Engl J Med 2008;358:2030-8.

34. Soubeyrand S, Pope L, De Chasseval R, Gosselin D, Dong F, de Villartay JP, et al. Artemis phosphorylated by DNA-dependent protein kinase associates preferentially with discrete regions of chromatin. J Mol Biol 2006;358: 1200-11.

35. Wang J, Aroumougame A, Lobrich M, Li Y, Chen D, Chen J, et al. PTIP associates with Artemis to dictate DNA repair pathway choice. Genes Dev 2014;28:2693-8.

36. Huang Y, Giblin W, Kubec M, Westfield G, St Charles J, Chadde L, et al. Impact of a hypomorphic Artemis disease allele on lymphocyte development, DNA end processing, and genome stability. J Exp Med 2009;206:893-908.

37. Jacobs C, Huang Y, Masud T, Lu W, Westfield G, Giblin W, et al. A hypomorphic Artemis human disease allele causes aberrant chromosomal rearrangements and tumorigenesis. Hum Mol Genet 2011;20:806-19.

38. Multhaup M, Karlen AD, Swanson DL, Wilber A, Somia NV, Cowan MJ, et al. Cytotoxicity associated with artemis overexpression after lentiviral vectormediated gene transfer. Hum Gene Ther 2010;21:865-75. 


\section{METHODS}

\section{Quantitative real-time PCR}

RNA was extracted from all DCLRE1C mutants by using TRIzol (Ambion; Life Technologies, Carlsbad, Calif) and subsequently reverse transcribed into cDNA (qScript; Quanta Biosciences, Gaithersburg, Md). Quantitative PCR ( $\triangle \Delta \mathrm{CT}$ method) was performed for human DCLRE1C (forward, 5' TCCCAGTCAACACACATAACA-3'; reverse, 5'-GTCAGCTTTGTCCAAG GAAGTA-3') and human CD2 (forward, 5'-GGGAACAAAGTCAGCA AGGA-3'; reverse, 5' -TGCCACAAAGACCATCAAGAG-3') expression by using SYBR green (Applied Biosystems, Life Technologies). $\beta_{2}$-Microglobulin (forward, 5'-CCTGCAGAGTTAAGCATGCCA-3'; reverse, 5'-TGCTT GATCACATGTCTCGATTCC-3') was used as a housekeeping gene, and WTa was used as an endogenous control.

RNA was extracted from all DCLRE1C mutants by using TRIzol (Ambion; Life Technologies, Carlsbad, Calif) and subsequently reverse transcribed into
cDNA (qScript; Quanta Biosciences, Gaithersburg, Md). Quantitative PCR ( $\triangle \Delta \mathrm{CT}$ method) was performed for human DCLRE1C (forward, 5'-TCCC AGTCAACACACATAACA-3'; reverse, 5'-GTCAGCTTTGTCCAAGGAA GTA-3') and human $C D 2$ (forward, 5'-GGGAACAAAGTCAGCAAGGA3'; reverse, 5'-TGCCACAAAGACCATCAAGAG-3') expression by using SYBR green (Applied Biosystems, Life Technologies). $\beta_{2}$-Microglobulin (forward, 5'-CCTGCAGAGTTAAGCATGCCA-3'; reverse, 5'-TGCTTGAT CACATGTCTCGATTCC-3') was used as a housekeeping gene, and WTa was used as an endogenous control.

\section{Cell-cycle analysis}

Cell-cycle phases were analyzed by using the Click-iT EdU Alexa Fluor 647 Flow Cytometry Assay Kit (Invitrogen, Life Technologies). Cells were pulsed with $10 \mu \mathrm{mol} / \mathrm{L}$ EdU for 2 hours at $37^{\circ} \mathrm{C}$ and subsequently fixed, permeabilized, and stained, according to the manufacturer's instructions. 
A

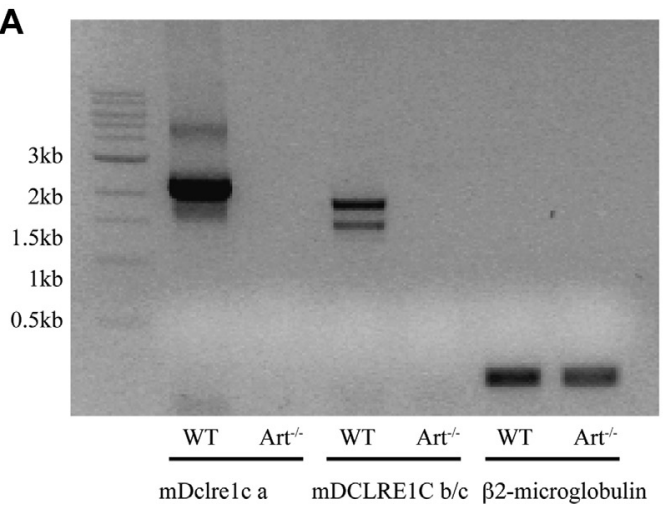

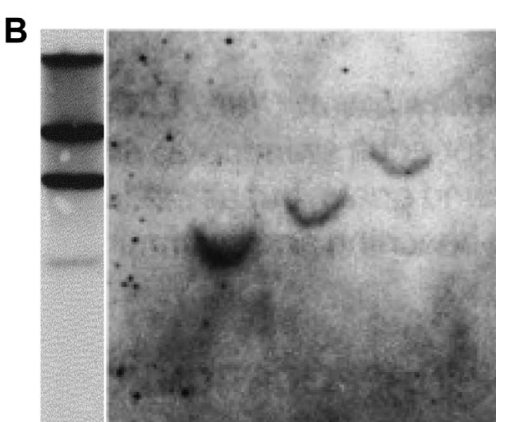

EcoRI NcoI HindIII

FIG E1. Characterization of Dclre $1 c^{-1-}$ abl pro-B cells. A, The lack of Dc/re1c expression (isoforms a, b, and c) in the abl pro-B cells used was confirmed by means of PCR. B, Dclre $1 c^{-/-}$abl pro-B cells were engineered with a retroviral vector containing an inverted GFP cassette and the human $C D 4$ sequence. Single-cell clones were selected, and a single vector copy integration was confirmed by means of southern blotting after digesting genomic DNA with EcoRI, Ncol, and HindlII. 
No Treatment

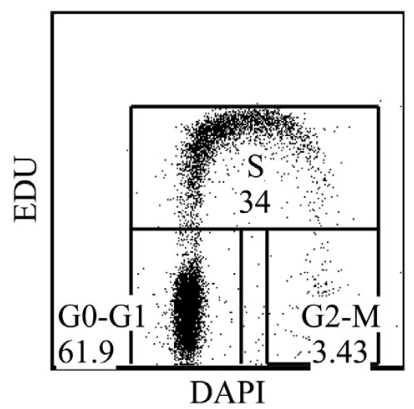

STI $(3 \mu \mathrm{M})$

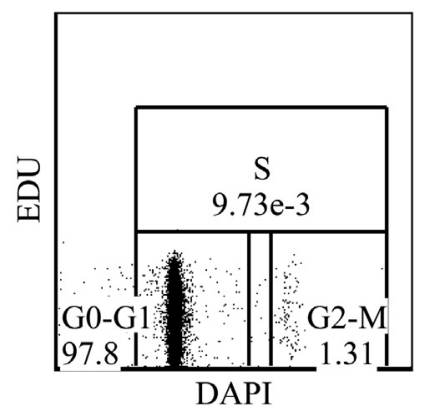

FIG E2. Cell-cycle block with imatinib. For analysis of recombination and DNA repair activities, Dc/re $1 c^{-/-}$abl pro-B cells were blocked in the G0/G1 cell-cycle phase by means of treatment with $3 \mu \mathrm{mol} / \mathrm{LO}$ of the tyrosine kinase inhibitor imatinib. 
A

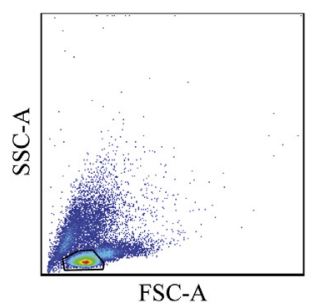

FSC-A

mWT Isoform a

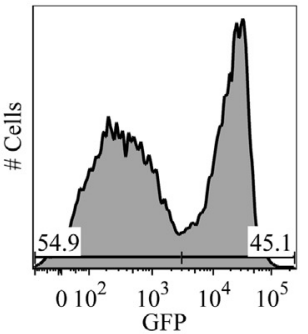

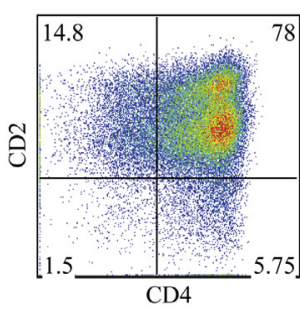

hWT Isoform a

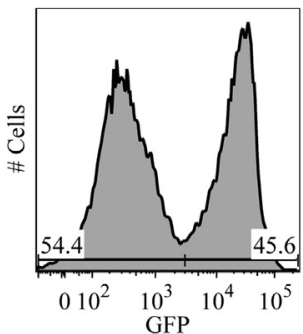

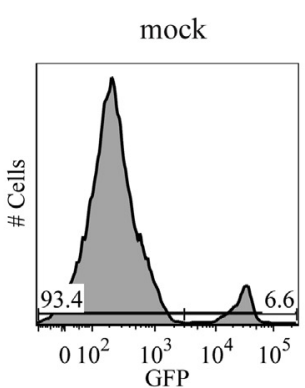

$\mathrm{hWT}$ Isoform b

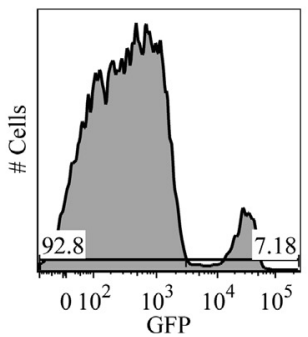

hWT Isoform c

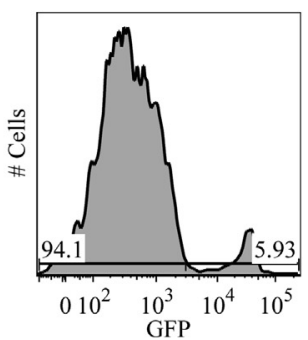

B

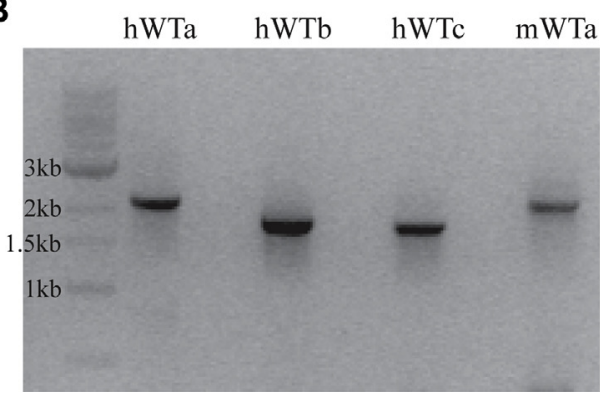

FIG E3. Functional activities of DCLRE1C and Dclre1c isoforms. A, To compare recombination activities of different isoforms, sequences of the human DCLRE1C isoforms $\mathrm{a}, \mathrm{b}$, and $\mathrm{c}$ and the murine Dc/re $1 \mathrm{c}$ isoform a were introduced into Dclre $1 c^{-/-}$abl pro-B cells engineered with the invGFP-hCD4 construct. GFP expression was assessed by means of flow cytometry in cells enriched for expression of both constructs $\left(\mathrm{CD} 4^{+} \mathrm{CD} 2^{+}\right)$. B, Expression of murine Dclre1c and human DCLRE1C transcripts was confirmed by means of PCR with cDNA as templates. DAPI, 4'-6-Diamidino-2-phenylindole dihydrochloride. 


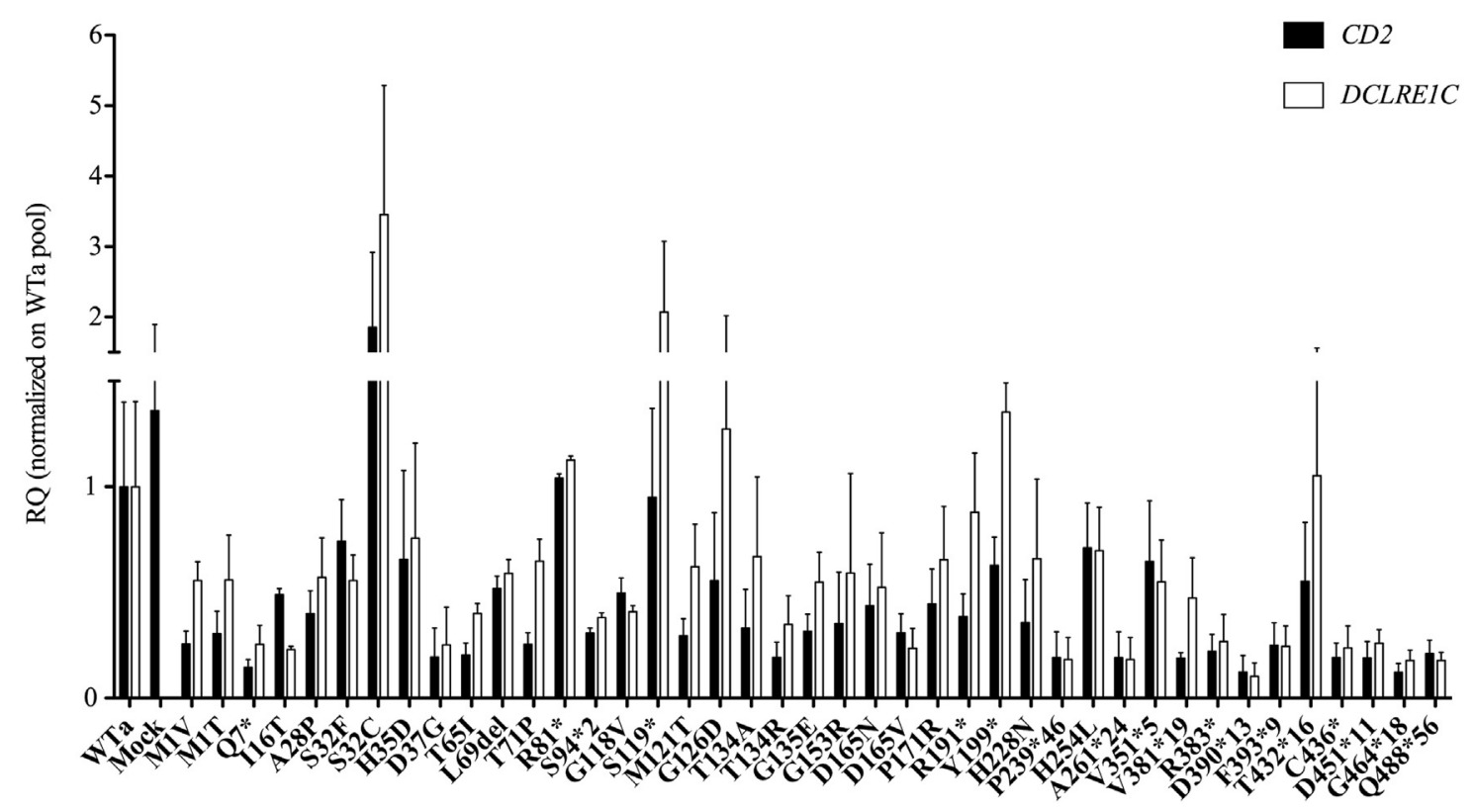

FIG E4. Quantification of WT and mutated DCLRE1C expression. Expression of DCLRE1C and CD2 was assessed by means of quantitative PCR ( $\triangle \Delta C T$ method) in CDNA from all mutant clones analyzed. $\beta_{2}$-Microglobulin was used as a housekeeping gene, and expression levels were normalized to WTa. 


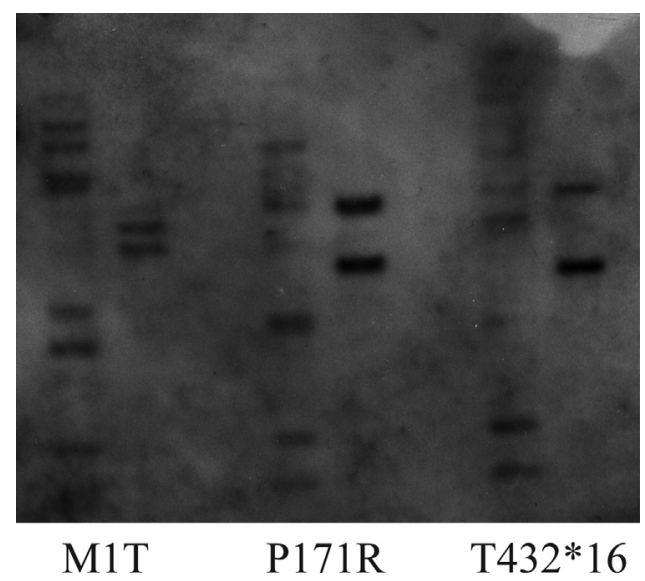

FIG E5. Three Artemis variants reported in patients presenting with leaky SCID were selected for further study of recombination and DNA repair activity levels in cells containing 6 or more or 2 vector copy numbers. The number of vector copy integrations was analyzed by means of Southern blotting of genomic DNA digested with EcoRI. 
TABLE E1. Predicted pathogenicity of DCLRE1C mutations

\begin{tabular}{|c|c|c|c|c|c|c|c|}
\hline \multirow{3}{*}{\multicolumn{2}{|c|}{ Mutations in DCLRE1C }} & \multirow{3}{*}{$\begin{array}{c}\text { Frequency in ExAC } \\
\text { genome browser }\end{array}$} & \multicolumn{5}{|c|}{ Prediction of Pathogenicity } \\
\hline & & & \multicolumn{3}{|c|}{ PolyPhen-2 } & \multicolumn{2}{|c|}{ SIFT } \\
\hline & & & Predicted & $\begin{array}{c}\text { Probability } \\
\text { HumDiv }\end{array}$ & $\begin{array}{c}\text { Probability } \\
\text { HumVar }\end{array}$ & Predicted & SIFT score \\
\hline \multicolumn{8}{|l|}{ Metallo- $\beta$-lactamase domain } \\
\hline c. $1 \mathrm{~A}>\mathrm{G}$ & M1V & & Probably damaging & 1 & 0.997 & Damaging & 0 \\
\hline c. $47 \mathrm{~T}>\mathrm{C}$ & I16T & 0.00001634 & Probably damaging & 0.999 & 0.984 & Damaging & 0 \\
\hline c. $82 \mathrm{G}>\mathrm{C}$ & $\mathrm{A} 28 \mathrm{P}$ & 0.000008191 & Probably damaging & 0.994 & 0.906 & Damaging & 0.03 \\
\hline c. $95 \mathrm{C}>\mathrm{T}$ & $\mathrm{S} 32 \mathrm{~F}$ & & Probably damaging & 1 & 1 & Damaging & 0 \\
\hline c. $95 \mathrm{C}>\mathrm{G}$ & $\mathrm{S} 32 \mathrm{C}$ & & Probably damaging & 1 & 1 & Damaging & 0 \\
\hline c. $103 \mathrm{C}>\mathrm{G}$ & $\mathrm{H} 35 \mathrm{D}$ & & Probably damaging & 1 & 1 & Damaging & 0 \\
\hline c. $110 \mathrm{~A}>\mathrm{G}$ & D37G & & Probably damaging & 0.997 & 0.951 & Damaging & 0.01 \\
\hline c. $353 \mathrm{G}>\mathrm{T}$ & G118V & & Probably damaging & 1 & 0.999 & Damaging & 0 \\
\hline c. $356 \mathrm{C}>\mathrm{G}$ & S119* & 0.000008364 & & & & & \\
\hline c. $362 \mathrm{~T}>\mathrm{C}$ & M121T & 0.000008387 & Probably damaging & 1 & 0.998 & Damaging & 0 \\
\hline c. $377 \mathrm{G}>\mathrm{A}$ & G126D & & Probably damaging & 1 & 0.997 & Damaging & 0.01 \\
\hline c. $400 \mathrm{~A}>\mathrm{G}$ & T134A & 0.000008154 & Probably damaging & 1 & 0.999 & Damaging & 0 \\
\hline c. $401 \mathrm{C}>\mathrm{G}$ & $\mathrm{T} 134 \mathrm{R}$ & & Probably damaging & 1 & 1 & Damaging & 0 \\
\hline c. $404 \mathrm{G}>\mathrm{A}$ & G135E & & Probably damaging & 1 & 1 & Damaging & 0 \\
\hline \multicolumn{8}{|l|}{$\beta$-CASP domain } \\
\hline c. $457 \mathrm{G}>\mathrm{A}$ & G153R & 0.01119 & Probably damaging & 0.977 & 0.512 & Tolerated & 0.19 \\
\hline c. $493 \mathrm{G}>\mathrm{A}$ & D165N & & Probably damaging & 1 & 1 & Damaging & 0 \\
\hline c. $494 \mathrm{~A}>\mathrm{T}$ & D165V & & Probably damaging & 1 & 1 & Damaging & 0 \\
\hline c. $512 \mathrm{C}>\mathrm{G}$ & P171R & 0.09040 & Benign & 0.014 & 0.098 & Tolerated & 0.08 \\
\hline c. $1147 \mathrm{C}>\mathrm{T}$ & R383* & 0.00001627 & & & & & \\
\hline \multicolumn{8}{|l|}{ C-terminal domain } \\
\hline c.1167_1168insAG & D390*13 & & & & & & \\
\hline c.1179delT & $\mathrm{F} 393 * 9$ & & & & & & \\
\hline c.1290_1306del17 & $\mathrm{T} 432 * 16$ & & & & & & \\
\hline c.1299_1306dupAGGATGCT & C436* & & & & & & \\
\hline c.1353_1359delTTGTGAA & $\mathrm{D} 451 * 11$ & & & & & & \\
\hline c.1391_1395delGAATC & $\mathrm{G} 464 * 18$ & & & & & & \\
\hline c.1464delG & $\mathrm{Q} 488 * 56$ & & & & & & \\
\hline
\end{tabular}

